\title{
ВІКІДИДАКТИКА - СКЛАДНИК НОВІТНЬОЇ МЕДІАДИДАКТИКИ В СОЦІАЛЬНІЙ МЕРЕЖІ ФЕЙСБУК
}

\author{
Білецький В. С., доктор технічний наук, професор, Національний технічний \\ університет «ХПI», Харків, Україна \\ Онкович Г. В., доктор педагогічних наук, професор, Київський медичний університет, \\ Київ, Украӥна
}

Онкович А. Д., кандидат педагогічних наук, магістр журналістики, доцент, Київський національний університет культури і мистецтв,, Київ, Україна

\section{DOI: https://doi.org/10.31435/rsglobal_conf/30082021/7645}

Abstract. The article deals with a new pedagogical branch of "wikididactics" and its presentation on Facebook. Wikididactics is considered as a part of pedagogy, which deals with the use of Wikipedia in the educational process, development and testing of new didactic materials based on Wikipedia sources.

Terminological base of the direction "Wikididactics" today includes the following concepts: wiki user, wikimedian, wikipedian, wiki educator, wikididact.

Wikididactics is the newest branch of modern media didactics, presented on the social network Facebook. The materials of the Facebook page are aimed at developing the media educational and socio-cultural competencies of its users. The results of the content analysis of the FB page "Wikididactics" are offered.

Keywords: media education, high school media didactics, wikididactics, wiki lesson, Internet resource, social network.

Вступ. Вікіпедія - глобальна, вільна та багатомовна інтернет-енциклопедія, найстаріший і найбільший проект Фонду Вікімедіа - найпопулярніший довідник в Інтернеті. Бурхливий процес іiі розвитку триває в усьому світі, що призводить до появи нових понять, термінів. Українські педагоги досить продуктивно використовують Вікіпедію у навчальному процесі. Так, В. Білецький і А. Бондаренко простежили роль Вікіпедії та ії̈ сестринських проектів у розвитку україністики [4], С. Бак i Н. Рудніцька [3] намагалась зреалізувати принцип метапредметності за допомогою вікіпроектів під час викладання зарубіжної літератури, С. Дячок розглядала вікіпроекти як форму виховання [11], В. Кодола започаткувала вікітренінги для педагогів [12], О. Кущ пропонував освітній вікі-курс у ліцеї [14] тощо. Найбільший внесок у розвиток Освітньої програми українського сектора Вікіпедії здійснили шкільні вчителі, які провели кілька вікітренінгів i вебінарів для українських педагогів, започаткували цілий напрямок, означений проф. Г.В. Онкович терміном «вікідидактика» [2]. Ці процеси відстежуються на сторінках вікіспільнот у мережі Фейсбук. Ідеї вікіуроків буквально носилися в освітньому просторі, адже з'ява такого корисного майданчика, як Вікіпедія, не могла пройти непоміченою і не наштовхнути педагогів на творчий пошук. 3 опертям на їхній досвід і для його поширення в соціальній мережі Фейсбук було створено сторінки «Вікідидактика». «Вікіпедія в школі», «Вікістудія». На той час уже користувалися популярністю такі заходи, як вікітренінги, вікімуштри, вікімарафони, під час яких у різних установах проводились уроки творення Вікіпедії з метою залучити науковий загал до написання й редагування статей у вільній енциклопедії. Такі вікіуроки стали вже традиційними, їх об'єднує парасолькове поняття «вікідидактика» - використання Вікіпедії з освітньою метою [18, $20,21]$. Вікіуроки з'явилися в інформаційному просторі завдяки відеозаписам педагогів Валентини Кодоли й Андрія Гриценка. Приклади вікіуроків і вікіпроєктів із низки шкільних дисциплін у $2017 / 18$ рр. були опубліковані в «Інформаційному збірнику для директора школи та завідувача дитячого садка», інших виданнях, а приклади використання Вікіпедії на заняттях із конкретної навчальної дисципліни у вищій школі були представлені на низці наукових конференцій $\mathrm{i}$ науково-методичних семінарів $[21,22,23]$. Пізніше на допомогу освітянам прийшли вебінари.

Вікідидактика - один із новітніх складників медіадидактики, частина педагогіки, що розглядає Вікіпедію як актуальний навчальний посібник. Блог-сторінку «ВІКІДИДАКТИКА» створено у Facebook 17 вересня 2016 р. Адміністраторами групи «Вікідидактика» у ФБ стали відомі фахівці з педагогіки і автори багатьох статей у Вікіпедії. Станом на липень 2021 року 
група нараховувала понад 730 учасників. Мова матеріалів блогу переважно українська, окремі матеріали подаються англійською. Статус групи: Загальнодоступна (будь-хто може переглядати учасників групи та їхні дописи), Видима (будь-хто може знайти цю групу), Загальна (що передбачає універсалізацію користувачів за аспектами проблеми). Це повністю відповідає принципам участі у Вікіпедії - загальнодоступній вільній багатомовній онлайн-енциклопедії. Термінологічна база напрямку «Вікідидактика» сьогодні включає такі поняття: • вікікористувач - послуговувач матеріалами Вікіпедії, • вікімедійник - розробник програмного забезпечення, - вікіпедист - автор і редактор статей, • вікіпедагог - учитель, котрий використовує Вікіпедію у навчанні і вихованні, • вікідидакт — той, хто навчає техніці написання й редагування статей у Вікіпедії, а також створює відповідні навчально-методичні посібники тощо.

Задачами вікідидактики, зокрема, є: розробка і апробація нових дидактичних матеріалів з використанням вікіпедійних джерел; розробка і впровадження різновидів уроків (вікіуроки, предметні (з літератури, географії, історії тощо), виховних уроків, «людина з Вікіпедії», «людина до Вікіпедії», уроки-подорожі, уроки за матеріалами вікіпроектів, уроки за матеріалами Фотоконкурсів тощо); вікітренінги; розробляння і впровадження різновидів лекцій для студентів: вікілекції, предметні заняття; створення вікістудій і вікішкіл у вишах; написання рефератів, оглядових статей тощо.

Мета статті - представити освітні можливості Вікіпедії через сторінку «Вікідидактика» в мережі Фейсбук, звернути увагу на основні потреби користувачів сторінки. Для досягнення мети ставимо такі завдання: - запропонувати для розгляду поняття «вікідидактика» як складник парасолькового поняття «медіадидактика»: - простежити історію з'яви, роль і місце ФБ сторінки «Вікідидактика» в сучасному освітньому-інформаційному просторі; - проаналізувати географію користувачів фахової ФБ сторінки «Вікідидактика», параметри їх активності; - проаналізувати часові виміри запиту інформації, активність користувачів за віковими категоріями; - спрогнозувати розвиток вікідидактики у контексті розвитку медіаосвіти 3 опертям на фахову зацікавленість педагогів ресурсом Фейсбук «Вікідидактика».

Методи. Для досягнення поставленої мети використовувалися такі методи, як спостереження, узагальнення, комп'ютерний контент-аналіз тощо. Вище ми назвали кілька форм освітніх занять 3 написання і редагування статей до Вікіпедії. На сьогодні маємо кількох дописувачів до вільної енциклопедії, котрі уважно стежать за процесами «навколо», узагальнюють їх, порівнюють. Серед таких авторів - Ю. Пероганич, В. Білецький, А. Бондаренко, Є. Букет, А. Луцюк $[4,7,8]$. Наприклад, від них, зокрема, ми дізнаємося про те, що «Відкрита 15 січня 2001 року англомовна Вікіпедія була першою вільною енциклопедією в Інтернеті й донині залишається найбільшим мовним розділом Вікіпедії у світі. Цьому сприяє як велика кількість людей, для яких англійська є рідною, так і те, що англійська де-факто $є$ мовою міжнаціонального спілкування. За статистикою, 39,3\% редагувань англійського мовного розділу здійснюється 3 території США, 16,2\% - Великої Британії, 6,2\% - Канади, 5,1\% - Індії, 4,1\% - Австралії. Тоді як, наприклад, 90,9\% редагувань української Вікіпедії здійснюється з території України» (С. Букет). Або: «Ми порахували статистику і побачили ось так найкращу українську десятку (йдеться про статті в українській Вікіпедії за рейтингом): Україна, Тарас Григорович Шевченко, Київ, Іван Франко, Леся Українка, Друга світова війна, Київська Русь, Львів, Перша світова війна, Німеччина. Деякі статті є популярними постійно. А. Бондаренко зазначає, що у кращій сотні статей стабільно перебувають 22 статті - про Україну та населення України, Київську Русь $\mathrm{i}$ Галицько-Волинське князівство, про міста Київ і Львів, про видатних діячів минулого - Тараса Шевченка, Івана Франка, Лесю Українку та Богдана Хмельницького, про країни світу Німеччину, Свропейський Союз і Велику Британію, Польщу та Францію, про історичні події Першу та Другу світові війни й Чорнобильську катастрофу, а також статті “Білки”, “Бароко”, "Інтернет”, i, звичайно, "Українська мова". Деякі статті навпаки з'являються в топі, а потім відходять. Починаючи з 2014-го, популярними є статті про війну на сході України, а $з$ 2019-го несподівано на 3 місце вийшла стаття про перехід церковних громад до ПЦУ $[7,8]$.

Результати. Комп’ютерний контент-аналіз блогу «ВІКІДИДАКТИКА» в часових рамах «весна-літо 2021 року» проведено на основі ряду динамічних кривих та гістограм (рис.1), показує очевидну зацікавленість до проекту за показниками: кількість учасників (всього 737, при цьому 362 активних учасників; публікації за 60 днів весни 2021 р. - 35; водночас коментарі і реакції на публікації - 110). Публікації, коментарі та реакції нерівномірно розподілені по днях 
тижня (рис.1). (Принагідно зазначимо, що аналогічне дослідження було зроблено і на матеріалах сторінки з нафтогазової освіти [6]).

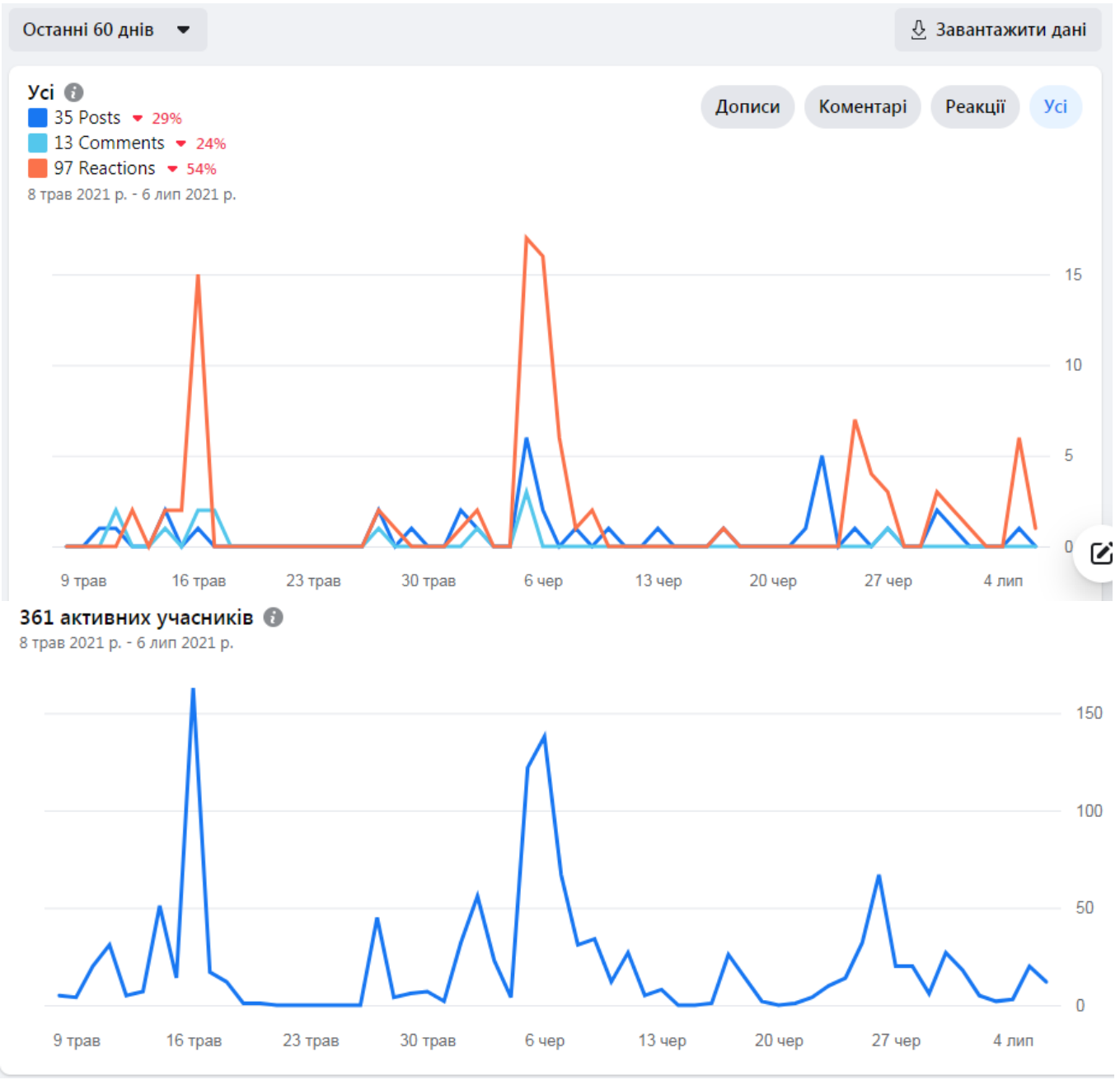

Рис. 1. Завантажені дані (дописи, коментарі, реакиіі) та активні учасники блогу «ВІКІДИДАКТИКА» за період 8 травня 2021 р. - 6 липня 2021 p.

Найбільш популярний день відвідин сайту - неділя. Популярні ранкові години - в околиці 10.00 (рис. 2).

\section{Популярні дні $i$}

Середня кількість разів, коли учасники групи публікують дописи, коментарі або реакції в певний день за вказаний період.

0

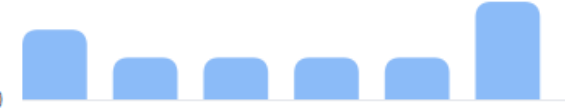

$\begin{array}{llllllll}\text { Пн } & \text { T } & \text { W } & \text { T } & \text { Пт } & \text { S } & \text { нд }\end{array}$
Популярні години $i$

Середня кількість разів, коли учасники групи публікують дописи, коментарі або реакції в певну годину дня за вказаний період.
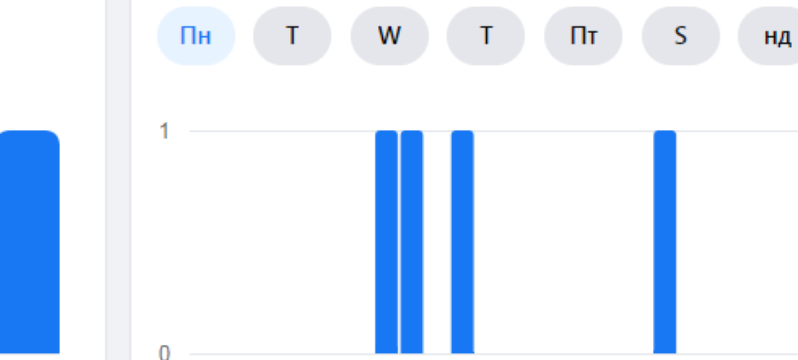

нд
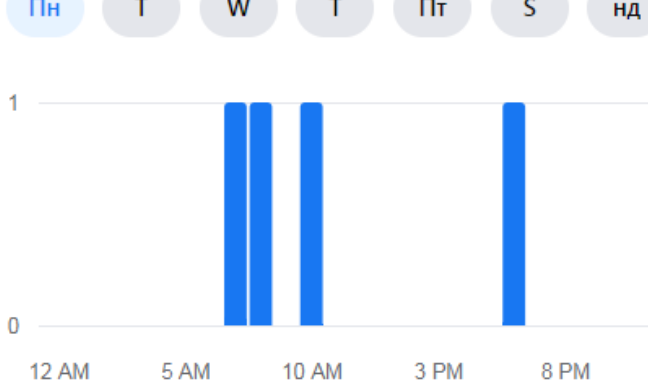

Рис. 2. Популярні дні і години відвідин сайту «ВІКІДИДАКТИКА»

Аналіз учасників блогу за віком і статтю (рис. 3) показує, що більшість учасників (74\%) - жінки, 26\% - чоловіки. 


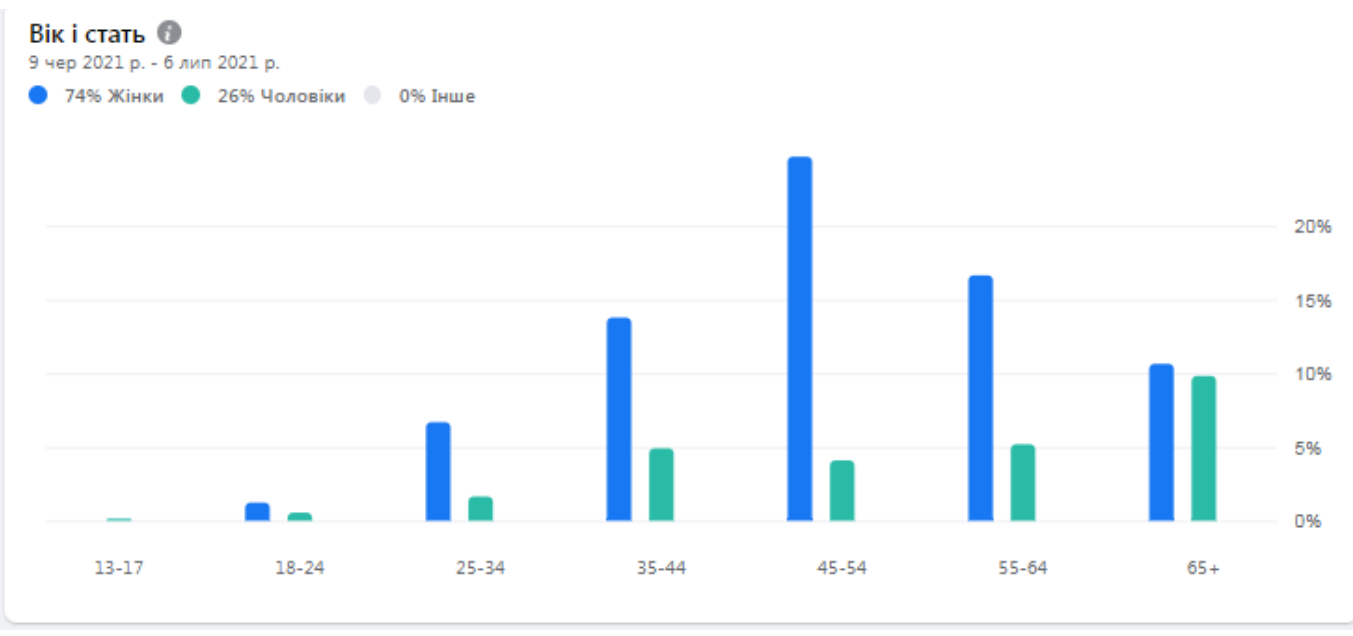

Рис. 3. Аналіз учасників блогу за віком і статтю.

Інтерес до матеріалів блогу найбільше виявляють вікові категорії 45-54-34 роки (до 30\% всіх учасників) та 55-64 роки (близько $17 \%$ учасників). Інтерес фахівців вікової категорії 35-44 років дещо нижчий - до $14 \%$, а 18-24 роки - незначний - близько $2 \%$ учасників блогу. Цікаво що категорія 65+ теж зберігає інтерес до тематики блогу і складає до $10 \%$ учасників.

Географія учасників блогу: Україна - 671 учасник, Росія і Білорусь - по 10-11, Італія 9, Сполучені Штати Америки - 7, Польща - 3, Мексика, Швейцарія, Ліван, Індія - по 2.

Популярні міста (по Україні): Київ - 250, Миколаїв - 63 (тут проводилося ряд заходів 3 популяризації Вікідидактики), Львів - 27, Запоріжжя та Івано-Франківськ - по 13, Одеса і Харків - по 11, Дніпро, Херсон і Луцьк - по 9.

\begin{tabular}{|c|c|c|c|}
\hline \multicolumn{2}{|l|}{ Популярні країни } & \multicolumn{2}{|l|}{ Популярні міста } \\
\hline Україна & 671 & Kyiv & 250 \\
\hline Росія & 11 & Mykolaiv, Mykolaiv Oblast & 63 \\
\hline Білорусь & 10 & Lviv, Lviv Oblast & 27 \\
\hline Італія & 9 & Zaporizhia, Zaporizhia Oblast & 13 \\
\hline Сполучені Штати Америки & 7 & Ivano-Frankivsk, Ivano-Frankivsk Oblast & 13 \\
\hline Польща & 3 & Odessa, Odessa Oblast & 11 \\
\hline Мексика & 2 & Kharkiv, Kharkiv Oblast & 11 \\
\hline Швейцарія & 2 & Dnipro, Dnipropetrovsk Oblast & 9 \\
\hline Ліван & 2 & Kherson, Kherson Oblast & 9 \\
\hline Індія & 2 & Lutsk, Volyn Oblast & 9 \\
\hline
\end{tabular}

Висновки. Таким чином, основний інтерес до Вікідидактики як нової та інноваційної частини педагогіки демонструє столичний регіон. Досвід Миколаєва показує можливості зростання такого інтересу на фаховому рівні після проведення ряду ознайомлювальних заходів та тренінгів. Тому можна говорити про перспективність його впровадження повсюдно в Україні починаючи від обласних центрів.

Чималий досвід використання Вікіпедії в освітньому процесі накопичений в різних країнах. Наприклад, Гіл Домінгес і Карла Тейшейра Лопес у статті Characterizing and comparing Portuguese and English Wikipedia medicine, опублікованій у травні 2019 року [10], зазначають, що «Вікіпедія - найбільша он-лайн спільна енциклопедія, що містить інформацію з безлічі полів, включно медицину», «Вікіпедія є одним 3 найбільш відвідуваних сайтів читачами, які шукають інформацію 3 цієї теми», «Велика залежність Вікіпедії від цього виду інформації 
спонукає до дослідження якості їі статей», для цього використовуємо такі показники, як повноваження, повнота, складність, інформативність, послідовність, а також вимірювання, що стосуються домену, для того, щоб оцінити та порівняти якість статей, пов'язаних 3 медициною, в англійській та португальській Вікіпедії». Як бачимо, дослідження зорієнтоване на працівників сфери охорони здоров'я, може наштовхнути на аналогічні аналізи статей із різних сфер життя соціуму, на порівняння дописів у різних мовних розділах Вікіпедії. Власним досвідом занять 3 опертям на матеріали Вікіпедії діляться й інші зарубіжні дослідники $[1,15]$.

Медіаосвітні технології, об'єднані поняттям «вікідидактика», розробляють й узагальнюють теоретико-методичні засади застосування Вікіпедії в освітньому процесі, зокрема, розробляють і впроваджують нові дидактичні матеріали 3 опертям на вікіджерела. Це й відображає аналізована сторінка в мережі Фейсбук.

\section{ЛІТЕРАТУРА}

1. Hoffmann S. Wikipedia in teaching: improving autonomy in research, critical sense, and collaborative abilities in students, making them contribute to the free encyclopedia. URL: http://maidanmuseum.org/uk/node/922 (дата звернення 15.01.2020)

2. Onkovych G. New in media education: wikididactics // The Fifth European Conference on Information Literacy (ECIL)/ September 18th-21st, 2017, Saint-Malo, France. Abstracts. Publisher: Information Literacy Association (InLitAs). P.250. URL: http://ecil2017.ilconf.org/wpcontent/uploads/sites/6/2017/09/ECIL-2017-Book-of-abstracts.pdf/ (дата звернення 15.01.2020)

3. Бак С. Реалізація принципу метапредметності за допомогою вікіпроектів під час викладання зарубіжної літератури/ Інформаційний збірник для директора школи та завідувача дитячого садка, 2018. Ч. 2 (71). C. 84-89.

4. Білецький В, Бондаренко А. Роль Вікіпедії та ії сестринських проектів у розвитку україністики. 8 Конгрес МАУ. Українознавство. Освіта, 2013. С. 40-52.

5. Білецький В.С., Онкович Г.В., Ткаченко М.В. Інженерна блогодидактика у нафтогазовій справі // Геотехнології, 2019. - Ч. 2. - С.55 - 63.

6. Білецький В.С., Онкович Г.В., Ткаченко М.В. Інженерна блогодидактика в навчальному процесі вищої школи (на прикладі підготовки фахівців нафтогазової сфери) PR и CMИ в Казахстане: сборник научных трудов. - Қазақстандағы PR және БАҚ: ғылыми еңбектер жинағы / сост. и гл. ред. Л.С. Ахметова. - Вып. 18. - Алматы: Қазақ университеті, 2020. - 426 с. ISBN 978-601-04-4546-8. -С. 155-171.

7. Бондаренко А. Українській Вікіпедії - 16 років: про що найбільше читають. URL: https://uain.press/blogs/ukrayinskij-vikipediyi-16-rokiv-pro-shho-najbilshe-chytayut-1164771? fbclid=IwAR2hSfzL1j7SxNyQysfkSRiLR634sgO1zRt7gnvUMiybDUzxuT4hxLp-aQ (дата звернення 15.01.2020)

8. Букет $€$. Найбільша енциклопедія за всю історію. URL: https://uain.press/blogs/najbilshaentsyklopediya-za-vsyu-istoriyu-1159455? fbclid=IwAR2Y-1qbR3IcbvYXY4638b89xxw Or VEvcEjK4383lhijudpdYcWuXyBW8U; Що таке Вікіпедія? URL: https://uain.press/blogs/yevgen-buketshho-take-vikipediya-659919? fbclid= IwAR3gaA6jfwDwd5YZ9J 3UL7SX3jW43eke R8yGWfZt9ZsR3O02nPeV51a9CU (дата звернення 15.01.2020)

9. Вікідидактика. Київ, 2016. URL: https://www.facebook.com/ groups/ 1796426670616724/ (дата звернення 15.01.2021)

10. Домінгес Г., Тейшейра Лопес. К. Characterizing and comparing Portuguese and English Wikipedia medicine //https: //www.researchgate.net/publication/333063606 (дата звернення 15.01.2020)

11. Дячок С. Вікіпроекти як форма виховання. Інформаційний збірник для директора школи та завідуючого дитячим садочком. РА "Освіта України", 2017. № 8. С. 69-73.

12. Кодола В. І. Вікіпедія в школі. Від медіаграмотності до медіакультури: стратегії, проблеми, перспективи: тези доповідей Міжнародної науково-практичної Інтернет-конференції (м. Миколаїв, 27 квітня 2016 року). Миколаїв: ОІППО, 2016. С. 37-40.

13. Кодола В. Технологія проведення вікіуроку. Інформаційний збірник для директора школи та завідувача дитячого садка, 2018. № 2 (71). С. 52-56.

14. Кущ О. Створення статей у Вікіпедії як форма самостійної роботи з учнями / Всесвітня література, 2017. № 3. C. $20-25$.

15. Махоні Е. Vicipedia Latina: Енциклопедія та співтовариство. The Classical Outlook, vol. 90. 3. 2015. pp. 68-90.

16. Національний медіаосвітній глосарій / Укл. Г. В. Онкович, В. Я. Карачун, Ю. Г. Карачун. Миколаїв: ОІППО, 2016. $120 \mathrm{c}$.

17. Онкович Г. В. Вікідидактика як інновація у мовній підготовці студентів. Збірник «Інновації та традиції у мовній підготовці студентів»: тези доповідей міжн.науково-практичного семінару. Х.: ХНУБА, 2017. С. 194-198.

18. Онкович Г. В. Нове в медіаосвіті: вікідидактика. Актуальні дослідження в соціальній сфері: матеріали десятої міжн. науково-практичної конференції (м. Одеса, 17 листопада 2017 р.) / гол. ред. В. В. Корнещук. Одеса: ФОП Бондаренко М.О., 2017. С. 146-148. 
19. Онкович Г. В. Новітні терміни медіаосвіти та медіадидактики. Лінгвістика. Лінгвокультурологія. Кроскультурна і міжкультурно комунікація: проблеми, питання, рішення. Дніпро, ДНУ ім. Олеся Гончара, 2018. № 12. Частина 2. С. 277-291.

20. Онкович Г. В., Онкович А. Д. Вікідидактика: формування і розвиток у системі професійної освіти. Вісник Житомирського державного університету імені Івана Франка. Педагогічні науки. Житомир: Вид-во Євенок О. О., 2017. Вип. 2 (88). С. 208-212.

21. Онкович Г. В., Онкович А. Д. Нове в медіаосвіті: вікідидактика. Мова і культура «Науковий журнал». К.: Видавничий дім Дмитра Бураго, 2017. Вип. 19. Т. V (185). С. 249-260.

22. Онкович Г. В., Онкович А. Д., Редько-Шпак Л. Вікідидактика: латиномовна Вікіпедія на заняттях 3 латинської мови у вищій школі/ Інновації та традиції у мовній підготовці іноземних студентів: тези доповідей міжнародного науково-практичного семінару. Х.: Вид-во Іванченка I, 2019. С. $276-282$.

23. Онкович Г. Вікідидактика та ії технології в системі відкритої освіти/ Донецький вісник Наукового товариства ім. Шевченка. Донецьк-Маріуполь-Покровськ: НТШ, 2018. С. 200-237.

24. Онкович Г., Онкович А., Редько-Шпак Л. Вікідидактика: Vicipedia Latina Латинськомовна Вікіпедія на заняттях з латинської мови у вищій школі / Соцікомунікативний простір України: історія та сьогодення: зб. матеріалів Всеукраїнської науково-практичної конференції до 125-річчя від дня народження М.Т. Рильського (Київ, 20-21 лютого, 2020 р.). Київ: Міленіум, 2020. С. 114-115.

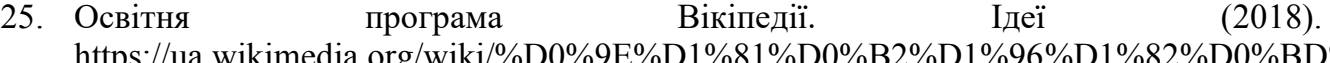
D1\%8F \%D0\%BF\%D1\%80\%D0\%BE\%D0\%B3\%D1\%80\%D0\%B0\%D0\%BC\%D0\%B0\%D0\% звернення 15.01.2020)

URL:

(дата 